\title{
ASSESSMENT OF SOIL EROSION BY Simulating RAINFALl ON AN EQUATORIAL ORGANIC SOIL
}

\author{
Johari, A.H. ${ }^{1}$, Law, P.L. ${ }^{1}$, Taib, S.N.L. ${ }^{1}$ and Yong, L.K. ${ }^{1}$ \\ ${ }^{1}$ Department of Civil Engineering, Universiti Malaysia Sarawak, 93000, Kota Samarahan, Sarawak, Malaysia.
}

Date received: 23/05/2017, Date accepted: 31/08/2017

Corresponding author's email: alifiahj@gmail.com

\begin{abstract}
Soil erosion occurs on construction sites partly due to site clearing that exposes the land to the erosive power of rainfall. A proposed construction project requires the submission of an Environmental Impact Assessment (EIA) to assess the impact of the project on the environment. Assessment of soil erosion is included in the EIA, but the equation to estimate soil erosion known as the Universal Soil Loss Equation (USLE) is only applicable to a soil containing up to four percent organic matter. This limitation of USLE requires an alternative that can predict soil erosion on an organic soil. This study attempts to assess erosion that occurs on an organic soil by simulated rainfall. Field soil samples were reconstructed into three shapes and exposed to simulated rainfall. Results indicate that the amount of organic soil loss decreases with increasing duration of rainfall. Particle size distribution shows that particles with sizes finer than coarse sand (1.7 $\mathrm{mm}$ ) remained on the slopes. Equations were developed from the graphs of soil loss versus duration of simulated rainfall to estimate soil loss occurring on slopes covered by an organic soil. The outcome of this study can be a precursor to developing an equation to estimate soil erodibility of a slope overlain by an organic soil.
\end{abstract}

Keywords: Soil erosion, organic soil, simulated rainfall, sediment yield.

\subsection{INTRODUCTION}

Road construction projects are developing in the country as an infrastructure to connect different places and to spur economic growth. Studies have been conducted on soil erosion occurring on construction sites, such as on highway embankments [1], roadside slopes [2] and soil deposits [3]. Soil erosion occurs on construction sites due to site clearing that exposes the land surface to erosion by rainfall and human activities.

An assessment of soil erosion on a proposed construction project is essential as it is included in the Environmental Impact Assessment (EIA), a legal document that is compulsory to be submitted for approval of the intended project. The provided equation to estimate soil erosion (USLE) is limited to land where the soil has a maximum organic matter content of four percent [4]. An assessment of soil erosion on a construction site with the soil containing more than four percent of organic matter such as an organic soil or peat would bring about errors. Therefore, an equation to estimate soil erosion on an organic soil should be developed. The aim of this study is to investigate the extent of soil erosion occurring on organic soil by simulating rainfall at a laboratory in Universiti Malaysia Sarawak, Malaysia. The scope of this study includes determining the characteristics of collected soil samples, conducting simulated rainfalls on three shapes of soil slopes, analysing the soil samples for particle size distribution, and analysing runoff samples for sediment yield. The assessment of soil erosion conducted on an equatorial organic soil would bring about an understanding of erosion that is occurring on a land that comprises an organic soil. Furthermore, relevant authorities and engineering consultants would be able to assess soil erosion on an organic soil with more accuracy.

Many researchers have designed and constructed different types of rainfall simulators for various objectives such as erosion, infiltration and sediment transport [5]-[7]. Rainfall simulators have several advantages over natural rainfall as the rainfall characteristics can be controlled and repeated at a suitable time [8]. However, rainfall simulators have other shortfalls such as difficulty in reproducing rainfall intensity fluctuations, distribution of drop sizes, and varied values of kinetic energy of raindrops. Without rainfall simulation, the study of soil erosion requires high temporal resolution and long-term 
rainfall records to calculate rainfall intensity and kinetic energy, which can be unavailable for some locations [9].

In natural conditions, the state of Sarawak encounters over $4000 \mathrm{~mm}$ of rainfall per year and rainfall can be expected on almost every day, particularly during the rainy season [10]. An increasing amount of rainfall could contribute to a higher index of rainfall erosivity and consequently higher soil erosion. The characteristics of soil samples and sediment yield can help determine the factors of rainfall erosivity and soil erodibility embedded in the Revised Soil Loss Equation (RUSLE). RUSLE was developed to predict top soil erosion rate from agricultural areas or plantations located in temperate regions with low rainfall $(1,000 \mathrm{~mm} /$ year) as compared to an equatorial region with more than $4,000 \mathrm{~mm} / \mathrm{year}$ such as Sarawak, where more than $25 \%$ of the area is covered with organic soil and peat [10], [11]. The different climate where the RUSLE was developed and its inability to determine sediment yield of an organic soil could bring about deviations in estimating soil erosion rate for an organic soil, particularly in an equatorial region like Sarawak. The closest estimation method so far was developed by [12], which is suitable for mineral soils and on slope areas in Peninsular Malaysia. If successful, the outcome of this study would lead to a more cost-effective, reduced operational and maintenance works, and more accurate prediction of soil loss generated annually.

\subsection{MATERIALS AND METHODS}

\subsection{Structure of Simulator}

The rainfall simulator is a steel frame structure with dimensions of $0.64 \mathrm{~m} \mathrm{x} 1.38 \mathrm{~m}$ at the base, $0.64 \mathrm{~m}$ $\mathrm{x} 1.38 \mathrm{~m}$ at the top and $1.0 \mathrm{~m}$ in height. The structure has a protruding triangle to support the sprinkler and is built with an adjustable steel angle of $30 \mathrm{~mm} \times 30 \mathrm{~mm} \times 5 \mathrm{~mm}$. The water tank, pumping unit, and sprinkler were temporarily located at a height of approximately 10.36 meters on the $2^{\text {nd }}$ floor of Chemical Engineering laboratory building in Universiti Malaysia Sarawak, Kota Samarahan, Malaysia.

The top of the main frame consists of an attached triangular structure to support the connecting hose and sprinkler. The sprinkler is $1.5 \mathrm{~m}$ in height from its base. The sprinkler is exposed to its surroundings to imitate natural rainfall. The source of water is a tap $25 \mathrm{~m}$ from the location of simulation. A submersible pumping unit is used to supply water to the sprinkler. The flow capacity of the pumping unit is a maximum of $13 \mathrm{~m}^{3}$ per hour. After calibration, the water pump was measured to be flowing at a rate of $0.436 \mathrm{~m}^{3} / \mathrm{h}$. Figure 3 shows the overall setting and where the rainfall simulator was placed.

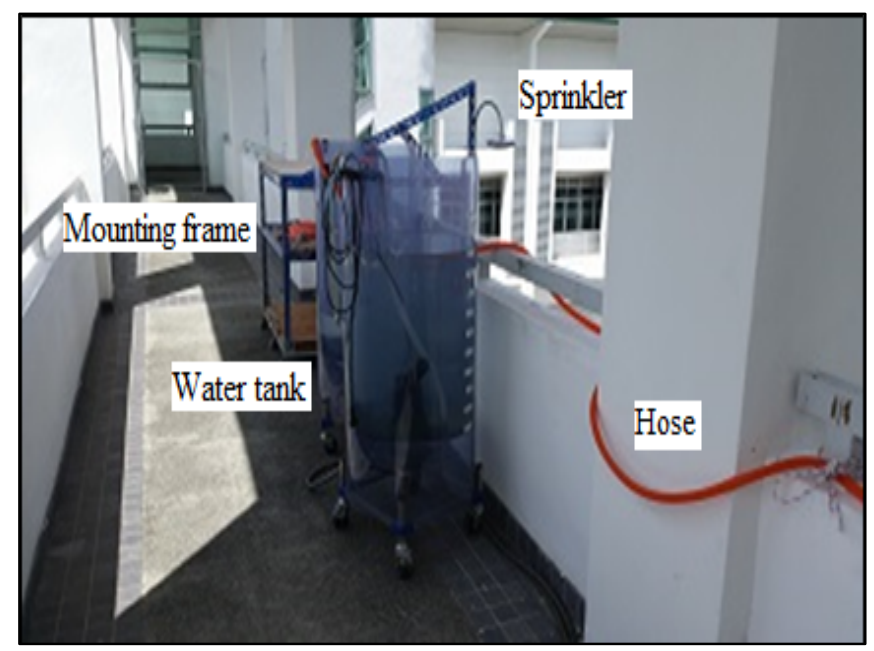

Figure 1 Rainfall simulator and water tanks placed on the $2^{\text {nd }}$ floor of a building in Universiti Malaysia Sarawak. 


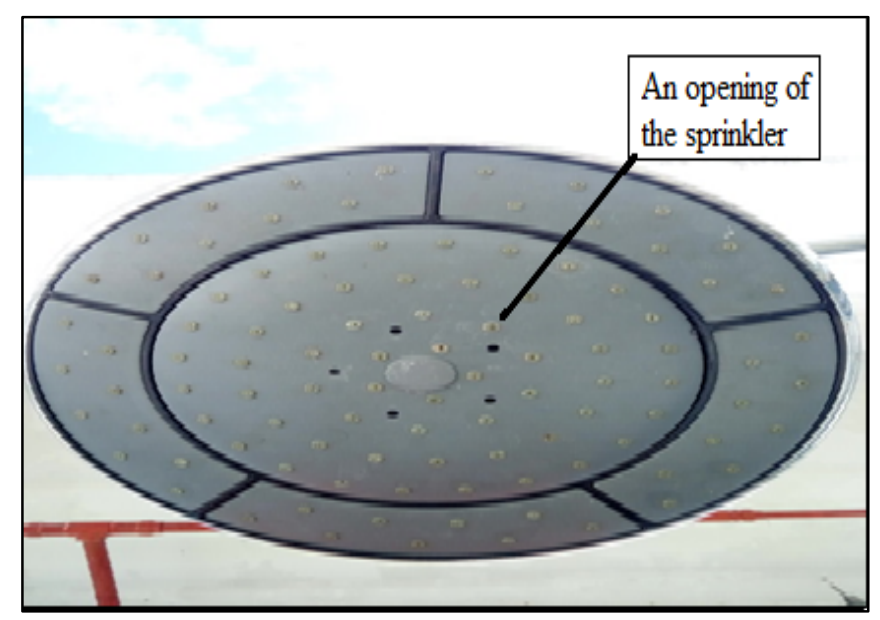

Figure 1 Nozzle openings are uniformly spaced.

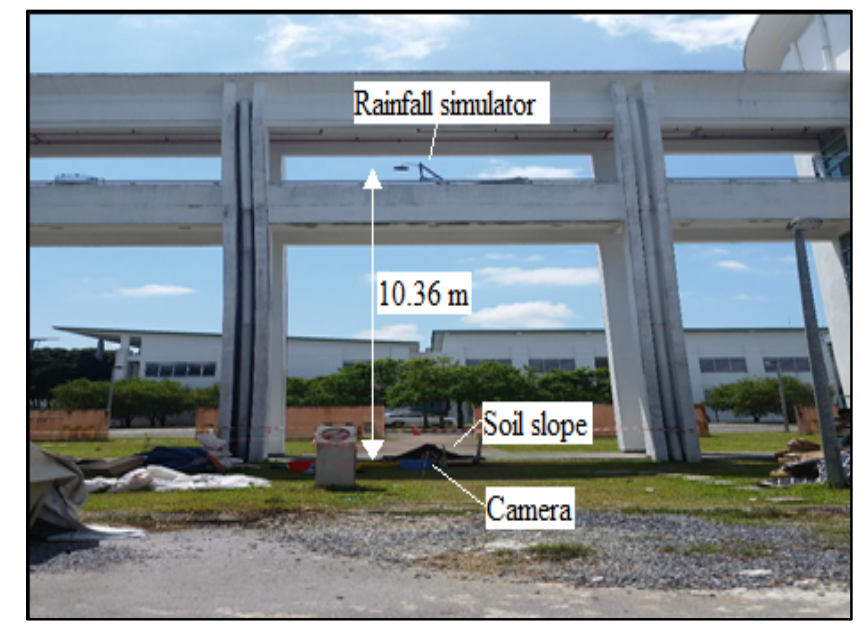

Figure 2 Set-up of rainfall simulator.

\subsection{Soil Slopes}

The soil used for this study was taken from Sri Aman, Sarawak (coordinate: $1^{0} 12$ '13" N, 111 ${ }^{0} 32$ '15" E), where the soil is visually classified as an organic soil. The soil sample weighed approximately $160 \mathrm{~kg}$ and was a disturbed sample. The soil was analysed for its physical properties. The approximate location of the soil sample is shown in Figure 4.

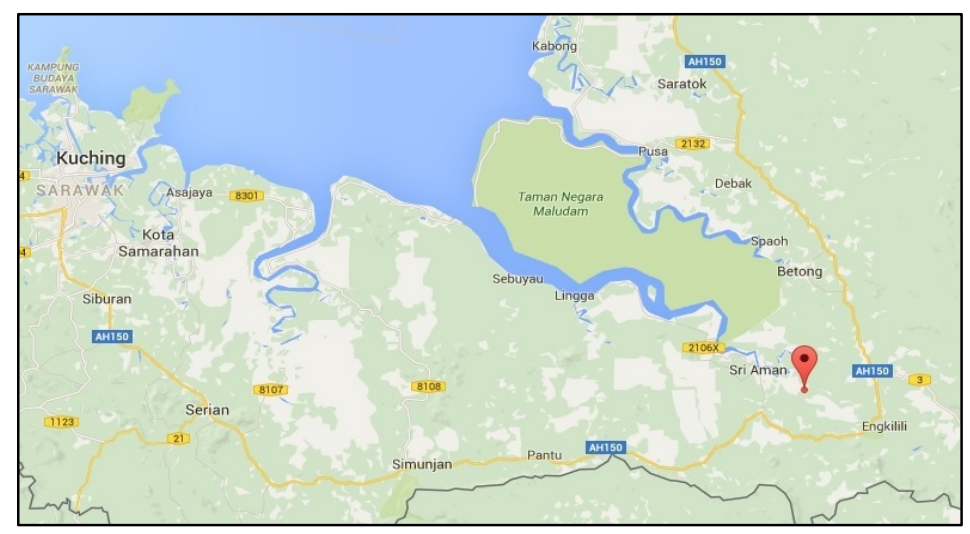

Figure 3 Soil sample location. (Accessed 10 $0^{\text {th }}$ April 2016, http://maps.google.com). 
There were three simulated rainfalls with different types of slopes; cone, pyramid, and plateau. The shape of slope was varied to facilitate sampling of soil during rainfall and to replicate real berm shapes. All slopes had a similar steepness of $45^{\circ}$. As shown in Table 1 , the cone-shaped slope was $1 \mathrm{~m}$ in diameter and $0.5 \mathrm{~m}$ in height. The loosely packed pyramid measured as $1 \mathrm{~m}$ by $1 \mathrm{~m}$ for the base and 0.5 $\mathrm{m}$ in height. The third slope was plateau-shaped with $1 \mathrm{~m}$ by $1 \mathrm{~m}$ at the base and $0.5 \mathrm{~m}$ in height. The flat surface at the top was $1 \mathrm{~m}$ in length by $60 \mathrm{~mm}$ in width.

Table 1 Characteristics of the studied soil.

\begin{tabular}{ccccc}
\hline Plot shape & Plot width $(\mathrm{m})$ & Plot length $(\mathrm{m})$ & Plot height $(\mathrm{m})$ & Slope (degrees) \\
\hline Cone & 1 (diameter) & - & 0.5 & 45 \\
Pyramid & 1 & 1 & 0.5 & 45 \\
Plateau & 1 (base), 0.06 (top) & 1 (base, top) & 0.5 & 45 \\
\hline
\end{tabular}

\subsection{Operation of Rainfall Simulator}

The rainfall simulator was run for 30 minutes.

\subsection{Collection of Soil Samples}

For each of the soil slopes, soil samples were collected at five selected points, beginning at the toe of slope and up the slope at an interval of $32 \mathrm{~mm}$. The weight of samples ranged from $50 \mathrm{~g}$ to $100 \mathrm{~g}$. One sample was collected at each point. Soil samples were collected after 15 and 30 minutes of simulation. Soil samples were taken at two times to compare the amount and particle sizes of soil being eroded by the rainfall.

\subsection{Analysis of Runoff}

Runoff was collected at intervals of six minutes for 30 minutes. The collected volume for each of the runoff samples was a minimum of 1 liter. A 1-liter volume is required to determine total suspended solids using standard method. The runoff samples were oven dried for 24 hours and then weighed to yield the value of Total Suspended Solids.

\subsection{Analysis of Soil Samples}

According to Malaysian Soil Classification System for Engineering Purposes and Field Identification, soil that contains $3 \%$ to $20 \%$ organic matter is termed slightly organic soil, $20 \%$ to $75 \%$ is termed organic soil and organic content more than $75 \%$ is termed peat. For this study, there were several physical characteristics to be determined; field density, organic content, specific gravity, particle size distribution, and permeability. All procedures were conducted according to British Standard BS8110:1995.

Particle size distribution was analysed to study the composition of the eroded soil. Total suspended solids was analysed to study the amount of soil being eroded. An empirical equation was generated for every rainfall simulation to provide an estimate of sediment yield.

\subsection{RESULTS AND ANALYSIS}

\subsection{Physical Properties of Soil Samples}

The physical properties of the soil samples are presented in Table 2. The average moisture content of the soil sample was $605.33 \%$. The average organic content was $88.25 \%$. Field density of the samples taken on site was $0.23 \mathrm{Mg} / \mathrm{m}^{3}$. The average value of hydraulic conductivity was $2.83 \times 10^{-4} \mathrm{~cm} / \mathrm{s}$. From 
sieve analysis, the mineral component of the soil samples had average values of $47.145 \%$ coarse sand, $41.560 \%$ very fine sand, $4.792 \%$ silt, and $3.612 \%$ clay.

Table 2 Physical properties of soil samples

\begin{tabular}{cc}
\hline Physical properties & Average value \\
\hline Moisture content $(\%)$ & 605.33 \\
Organic content $(\%)$ & 88.25 \\
Field density $\left(\mathrm{Mg} / \mathrm{m}^{3}\right)$ & 0.379 \\
Specific gravity & 0.223 \\
Hydraulic conductivity $(\mathrm{cm} / \mathrm{s})$ & $2.83 \times 10^{-4}$ \\
\hline
\end{tabular}

Figure 5 presents the particle size distribution of soil samples collected on 5 points of the cone-shaped slope after 15 minutes. From the graph, most of the grains are retained on sieve size of $150 \mu \mathrm{m}$ with a range of $38.45 \%$ to $59.82 \%$, and on sieve size of $1.7 \mathrm{~mm}$ with a range of $30.59 \%$ to $55.24 \%$. Figure 6 presents particle size distribution for Samples 6-10 collected after 30 minutes. Most of the grains with an average of $47.44 \%$ were retained on sieve size of $1.7 \mathrm{~mm}$. Generally, most of the particles smaller than $1.7 \mathrm{~mm}$ were retained on the slopes. According to British Standard Institute, soil particles finer than $10 \mathrm{~mm}$ are considered as gravel. Soil particles that pass through a $1.7 \mathrm{~mm}$ sieve are classified as coarse and medium coarse sand. Soils finer than $150 \mu \mathrm{m}$ are categorised as fine sand, and soils that pass through a $63 \mu \mathrm{m}$ sieve are considered as clay [13], [14].

Figure 7 displays the particle size distribution of soil samples for the pyramid-shaped slope with Samples 11-15. The samples were collected after 15 minutes of rainfall simulation. As shown in the graph, the $1.7 \mathrm{~mm}$ sieve retained the highest percentage of the soil sample, with an average content of $53.45 \%$. Figure 8 shows the particle size distribution of Samples 16-20. The $1.7 \mathrm{~mm}$ sieve retained the highest percentage of grains, with an average of $58.18 \%$. An average of $32.35 \%$ of the samples were retained on sieve size $150 \mu \mathrm{m}$. Figures 9 and 10 describe the particle size distribution the plateaushaped slope, Samples 21-30. From Figure 9, an average 49.67\% of the samples (Samples 21, 22, 23, and 25) were retained on a sieve size of $150 \mu \mathrm{m}$, and an average of $37.63 \%$ of the samples retained on sieve size $1.7 \mathrm{~mm}$. Figure 10 shows sieve size $1.7 \mathrm{~mm}$ retained most of the samples with an average of $43.88 \%$. Sieve size of $150 \mu \mathrm{m}$ held $43.56 \%$ of the grains. Different trends were collected from the plateau-shaped slope, where Sample 1 and 6 have the most soil retained on sieve sizes of $150 \mu \mathrm{m}$ and pan (smaller than $63 \mu \mathrm{m}$ ). These different results may be due to smaller grains that have sufficient time to be displaced descending the slope to the edge of the tray.

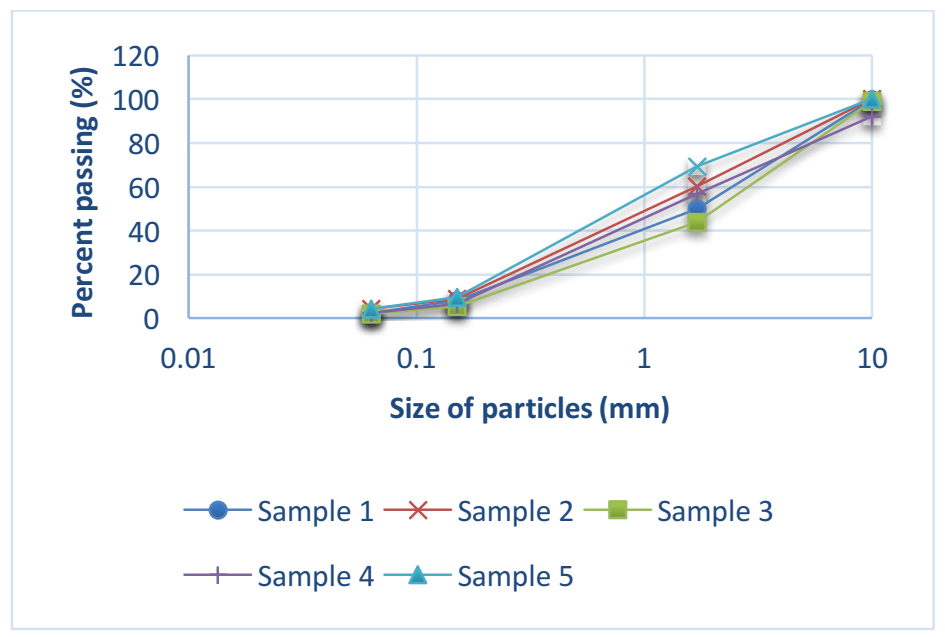

Figure 5 Particle size distribution of eroded soil after 15 minutes of rainfall simulation on cone-shaped slope. 


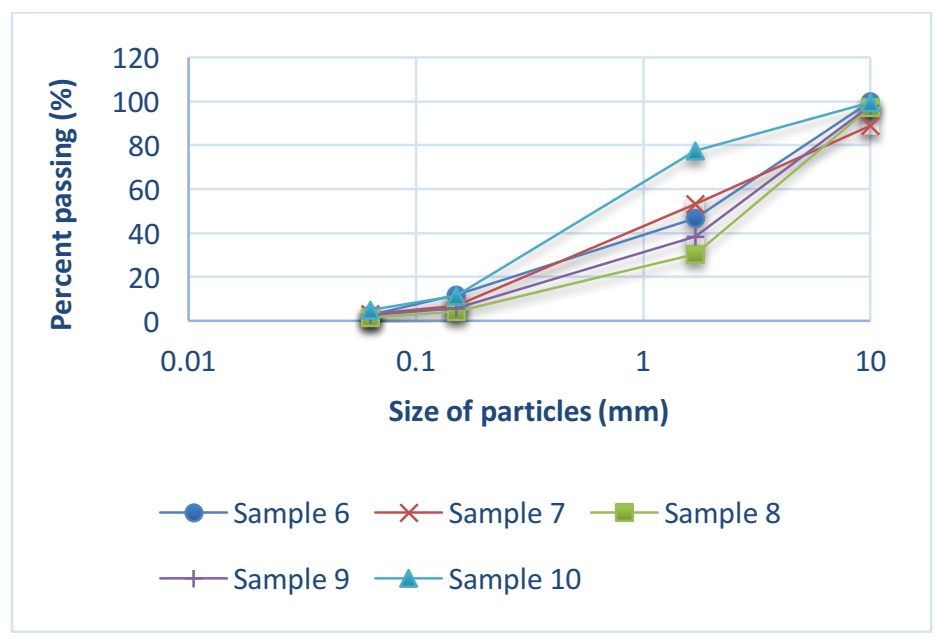

Figure 6 Particle size distribution of eroded soil after 30 minutes of rainfall simulation on cone-shaped slope.

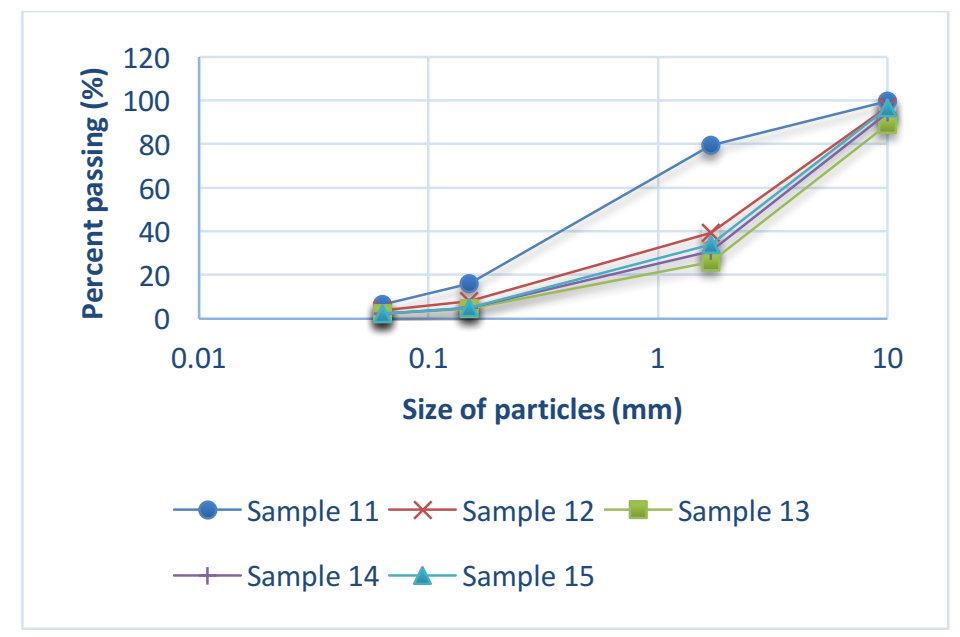

Figure 7 Particle size distribution for eroded soil after 15 minutes of rainfall simulation on pyramid-shaped slope.

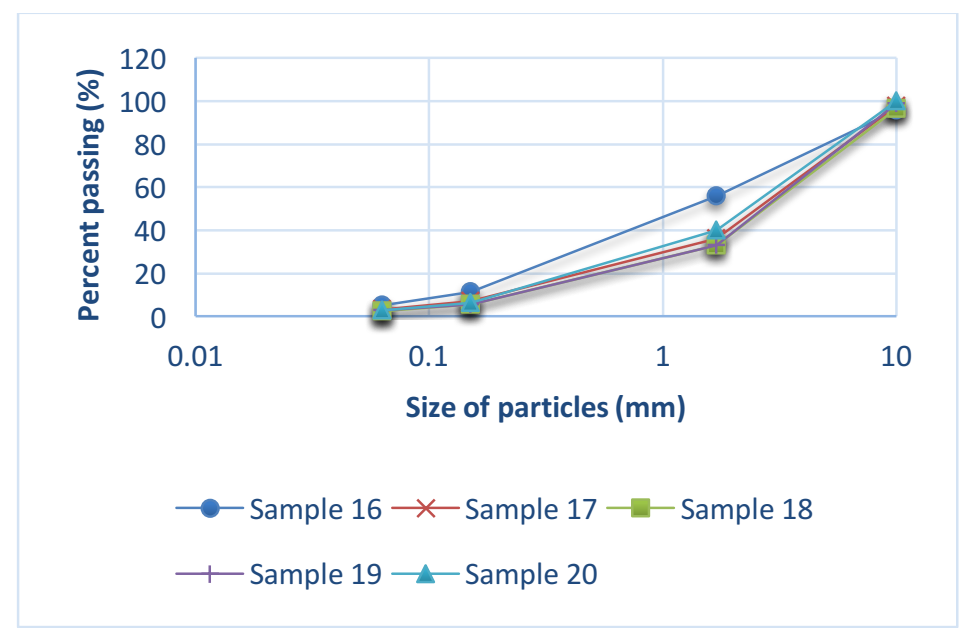

Figure 8 Particle size distribution for eroded soil after 30 minutes of rainfall simulation on pyramid-shaped slope. 


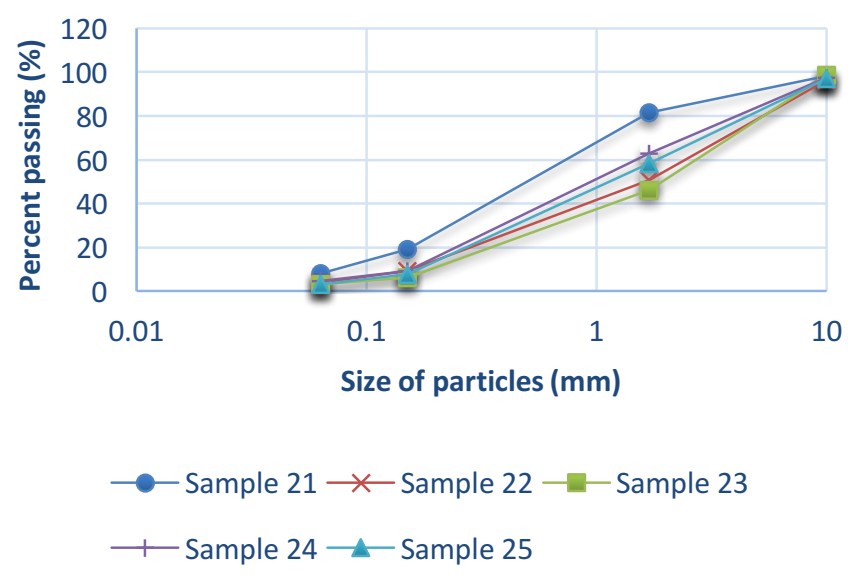

Figure 9 Particle size distribution of eroded soil after 15 minutes of rainfall simulation on plateau-shaped slope.

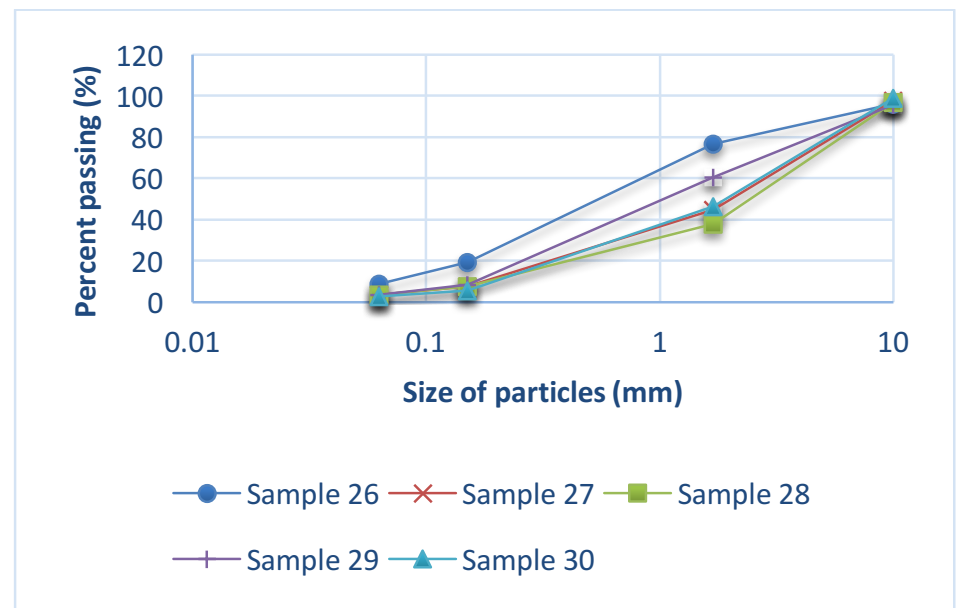

Figure 10 Particle size distribution of eroded soil after 30 minutes of rainfall simulation plateau-shaped slope.

\subsection{Determination of Sediment Yield}

To determine sediment yield, runoff was collected at 6 minute intervals after simulated rainfall had started. The runoff in the basin was stirred and kept in a 1.5-L bottle. A 1-liter volume of runoff was dried for 24 hours. The sediment in the dried runoff was weighed to measure sediment concentration. Sediment yield was determined by multiplying the sediment concentration with total estimated volume of runoff.

Table 3 shows sediment yield for one minute of simulated rainfall. The sediment yield was extrapolated from the time interval of when the runoff sample was taken and then multiplied by 6 minutes. Figure 11 is the graphical representation of sediment yield of the cone-shaped soil slope. Figure 11 also shows linear correlation of sediment yield in ton.ha ${ }^{-1} .(6 \text { minutes })^{-1}$ by curve fitting using Microsoft Excel. The coefficient of determination $\left(\mathrm{R}^{2}\right)$ of the linear equation shows a ratio of 0.5144 . For the duration of 30 minutes of simulated rainfall, total sediment yield generated from soil erosion for cone-shaped soil slope was 3.58 tons per ha.

Table 4 presents the sediment yield on the pyramid-shaped slope for 30 minutes. Total sediment yield for the simulated rainfall is 15.81 tons per ha. Figure 12 shows the linear equation to determine sediment yield. The equation indicates a good correlation with $\mathrm{R}^{2}$ of 0.6113 . 
Table 5 describes sediment yield on the plateau-shaped soil slope, whereas Figure 13 displays the linear relationship of sediment yield over the duration of simulated rainfall. The graph shows that sediment yield is predicted to be reduced over duration of a rainfall event. The coefficient of determination indicates a good ratio of $R^{2}$ of 0.7517 . Total estimated sediment yield for the simulated rainfall was 4.80 tons per ha. The equations generated from the graphs of sediment yield versus duration in Figures 11-13 are summarised in Table 6 . The equations are required to estimate sediment yield occurring on slopes with similar characteristics and rainfall patterns.

Table 3 Correlation of sediment yield and duration of simulated rainfall.

\begin{tabular}{c|ccccc}
\hline Duration (minutes) & 6 & 12 & 18 & 24 & 30 \\
Total suspended solids $\left(\mathrm{g} / \mathrm{L} / \mathrm{m}^{2}\right)$ & 7.00 & 6.38 & 3.07 & 5.00 & 4.00 \\
Sediment yield $(\mathrm{g} / \mathrm{ha} / \mathrm{min})$ & $1.64 \times 10^{5}$ & $1.49 \times 10^{5}$ & $7.20 \times 10^{4}$ & $1.17 \times 10^{5}$ & $9.38 \times 10^{4}$ \\
Sediment yield (ton $/ \mathrm{ha} / \mathrm{min})$ & 0.164 & 0.149 & 0.072 & 0.117 & 0.094 \\
\hline
\end{tabular}

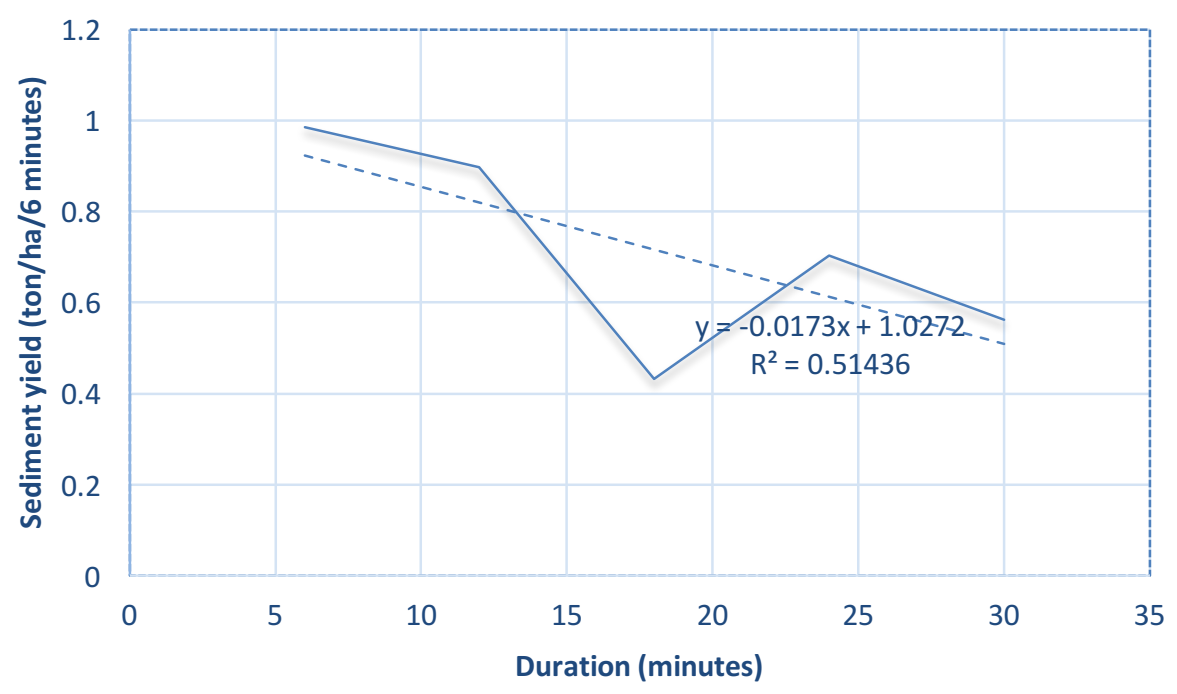

Figure 11 Extent of sediment yield on cone-shaped slope against duration and its regression equation.

Table 4 Sediment yield against duration of simulated rainfall on pyramid-shaped slope.

\begin{tabular}{c|ccccc}
\hline Duration (minutes) & 6 & 12 & 18 & 24 & 30 \\
Total suspended solids $\left(\mathrm{g} / \mathrm{L} / \mathrm{m}^{2}\right)$ & 50.42 & 24.00 & 8.00 & 18.00 & 12.00 \\
Sediment yield $(\mathrm{g} / \mathrm{ha} / \mathrm{min})$ & $1.18 \times 10^{6}$ & $5.62 \times 10^{5}$ & $1.87 \times 10^{5}$ & $4.22 \times 10^{5}$ & $2.81 \times 10^{5}$ \\
Sediment yield (ton $/ \mathrm{ha} / \mathrm{min})$ & 1.182 & 0.563 & 0.187 & 0.422 & 0.281 \\
\hline
\end{tabular}




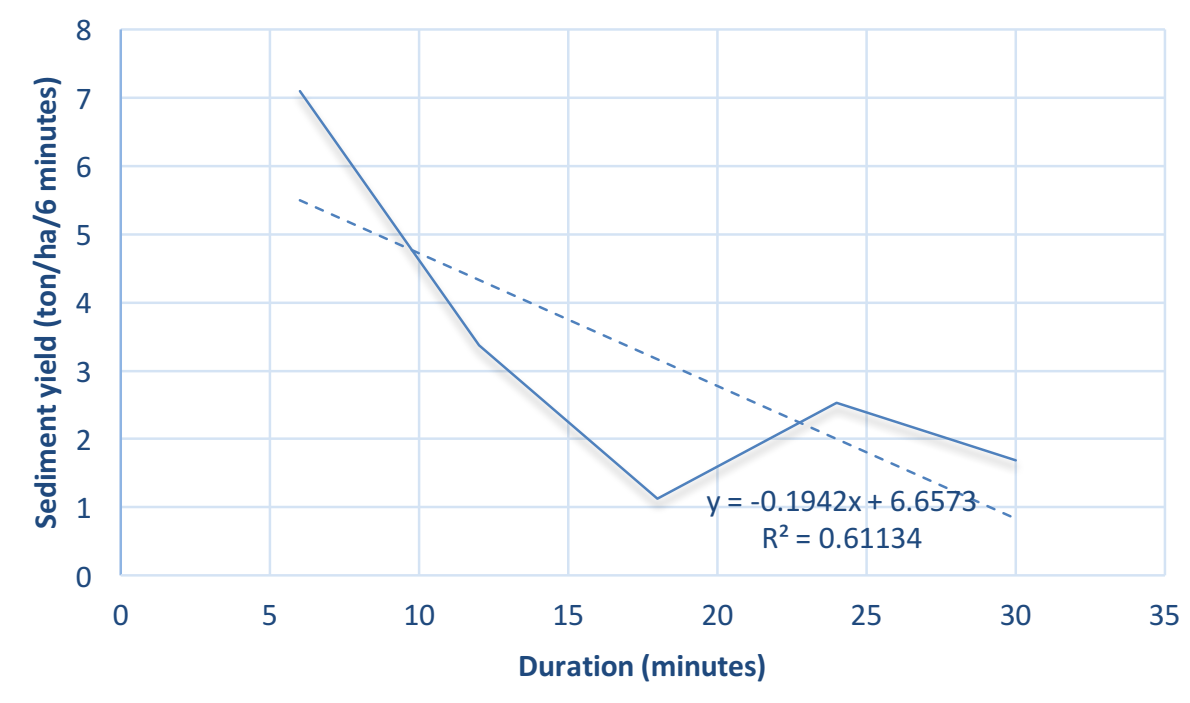

Figure 12 Progression of sediment yield on pyramid-shaped slope against duration of simulated rainfall.

Table 5 Sediment yield against duration of simulated rainfall on plateau-shaped slope.

\begin{tabular}{c|ccccc}
\hline Duration (minutes) & 6 & 12 & 18 & 24 & 30 \\
Total suspended solids $\left(\mathrm{g} / \mathrm{L} / \mathrm{m}^{2}\right)$ & 8.14 & 7.28 & 8.14 & 6.00 & 4.56 \\
Sediment yield $(\mathrm{g} / \mathrm{ha} / \mathrm{min})$ & $1.91 \times 10^{5}$ & $1.71 \times 10^{5}$ & $1.91 \times 10^{5}$ & $1.41 \times 10^{4}$ & $1.07 \times 10^{5}$ \\
Sediment yield (ton $/ \mathrm{ha} / \mathrm{min})$ & 0.191 & 0.171 & 0.191 & 0.141 & 0.107 \\
\hline
\end{tabular}

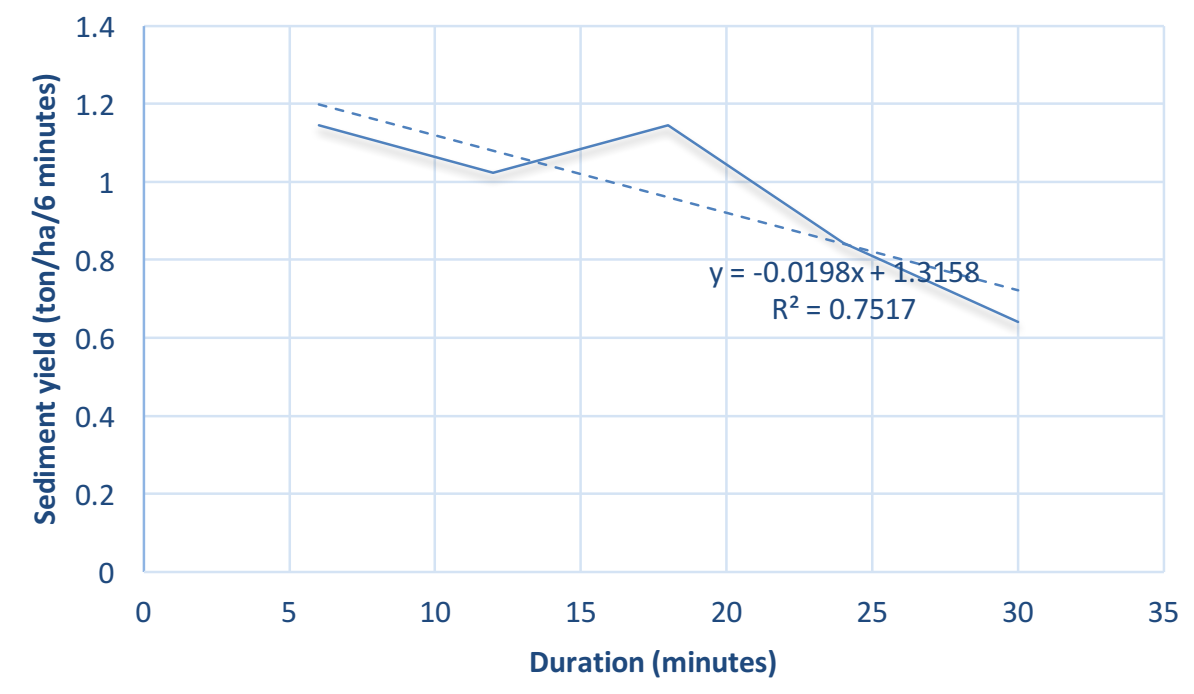

Figure 13 Correlation of sediment yield on plateau-shaped slope and duration of simulated rainfall.

Table 6 Summary of equations generated from the correlations of sediment yield and duration of simulated rainfall.

\begin{tabular}{ccc}
\hline Hill slope & Soil loss rate & $\mathrm{R}^{2}$ \\
\hline Cone & $\mathrm{y}=-0.0173 \mathrm{x}+1.0272$ & 0.5144 \\
Pyramid & $\mathrm{y}=-0.1942 \mathrm{x}+6.6573$ & 0.6113 \\
Plateau & $\mathrm{y}=-0.0198 \mathrm{x}+1.3158$ & 0.7517 \\
\hline
\end{tabular}




\subsection{CONCLUSIONS}

Results have shown that soil loss decreases with increasing duration of simulated rainfall. Sediment yield of cone-shaped slope from simulated rainfall was estimated at 3.58 tons per hectare. The estimated sediment yield of pyramid-shaped slope and plateau-shaped slope were 15.81 tons per hectare and 4.80 tons per hectare respectively. Particles with sizes of less than $1.7 \mathrm{~mm}$ were mostly deposited on the toe of slopes. This may be due to random arrangement of the soil particles in the soil plot. The shapes of the slopes (cone, pyramid and plateau) appeared to be indistinctive upon completion of the simulated rainfalls. Equations were generated from the correlations between sediment yield and duration of simulated rainfalls to estimate sediment yield for slopes containing an organic soil. The outcome of this study can serve as a preliminary investigation to generate a new equation to estimate soil erodibility of an equatorial organic soil, particularly in Sarawak.

\section{REFERENCES}

[1] R. A. Persyn, T. D. Glanville, T. L. Richard, J. M. Laflen, and P. M. Dixon, "Environmental effects of applying composted organics to new highway embankments: Part 1. Interrill runoff and erosion," Trans. ASAE, vol. 47, no. 2, p. 7, 2004.

[2] X. Z. Xu, H. W. Zhang, G. Q. Wang, S. C. Chen, and W. Q. Dang, "An experimental method to verify soil conservation by check dams on the Loess Plateau, China,” Environ. Monit. Assess., vol. 159, no. 1-4, pp. 293-309, 2009.

[3] J. Dong, K. Zhang, and Z. Guo, "Runoff and soil erosion from highway construction spoil deposits: A rainfall simulation study," Transp. Res. Part D Transp. Environ., vol. 17, no. 1, pp. 8-14, 2012.

[4] W. H. Wischmeier and D. D. Smith, Predicting rainfall erosion losses - A Guide to Conservation Planning, no. 537. 1978.

[5] G. S. Fifield, Field Manual on Sediment and Erosion Control Best Management Practices for Contractors and Inspectors. Santa Barbara, California, USA: Forester Press, 2001.

[6] L. Ooshaksaraie, N. E. A. Basri, A. A. Bakar, and K. N. A. Maulud, "Erosion and sediment control plans to minimize impacts of housing construction activities on water resources in Malaysia," Eur. J. Sci. Res., vol. 33, no. 3, pp. 461-470, 2009.

[7] I. A. R. Al-Ani, L. Mohd Sidek, M. N. Mohd Desa, and N. E.A.B., "Knowledge Based Expert System for Minimising Stormwater Erosion and Sedimentation in Malaysian Construction Sites," in Proceeding of the International Conference on Advanced Science, Engineering and Information Technology, 2011.

[8] S. Niu, X. Jia, J. Sang, X. Liu, C. Lu, and Y. Liu, "Distributions of Raindrop Sizes and Fall Velocities in a Semiarid Plateau Climate: Convective versus Stratiform Rains,” J. Appl. Meteorol. Climatol., vol. 49, no. Rotstayn 1997, pp. 632-645, 2010.

[9] A. Shamshad, M. N. Azhari, M. H. Isa, W. M. A. W. Hussin, and B. P. Parida, "Development of an appropriate procedure for estimation of RUSLE EI30 index and preparation of erosivity maps for Pulau Penang in Peninsular Malaysia," Catena, vol. 72, no. 3, pp. 423-432, 2008.

[10] Malaysian Meteorological Department, "General Climate of Malaysia," 2016. [Online]. Available: www.met.gov.my.

[11] M. Mohamed, E. Padmanabhan, B. L. H. Mei, and W. B. Siong, "The Peat Soils of Sarawak," 2002.

[12] K. H. Tew, Production of Malaysian soil erodibility nomograph in relation to soil erosion issues. Subang Jaya, Selangor: VT Soil Erosion Research and Consultancy, 1999.

[13] British Standard Institution, "British Standard Methods of Test for Soils for Civil Engineering Purposes BS1377-2," Br. Stand., p. 72, 1990.

[14] M. F. Yusof, R. Abdullah, H. M. Azamathulla, N. A. Zakaria, and A. A. Ghani, "Modified Soil Erodibility Factor, K for Peninsular Malaysia Soil Series," 3rd Int. Conf. Manag. Rivers 21st Century Sustain. Solut. Glob. Cris. Flooding, Pollut. Water Scarcity, pp. 799-808, 2011. 